\title{
DIVERSITY AND REGIONALISM IN INTERNATIONAL COMMERCIAL ARBITRATION
}

\author{
Adriana Braghetta*
}

New Zealand Law Foundation International Dispute Resolution Lecture 2015, delivered at Stone Lecture Theatre, Auckland Law School, 19 October 2015. The lecture focuses on diversity and regionalism in international commercial practice, looking specifically at the representation of new players

First of all, thank you all for being here for us to exchange a few ideas. Before I start I would like to heartily thank Carolina Foster and Petra Butler for the invitation to give this lecture tonight the New Zealand Law Foundation Dispute Resolution Lecture of 2015 - a joint initiative of the University of Auckland and the Victoria University of Wellington. I am extremely honoured. I hope you keep on bringing different people from around the globe to share thoughts with you, and I hope we can do the same in Brazil. The New Zealand Law Foundation invited me and funded my trip and for that again, I would like to thank Carolina Foster and Petra Butler.

I realise, first of all, that this lecture was created in 2012, and that before me at least two other women presented this lecture: Lucy Reed ${ }^{1}$ and Catherine Rogers. ${ }^{2}$ This is impressive as we are going to discuss tonight the issue of diversity. It shows that Carolina and Petra pay attention to this

* Professor and Coordinator of the Arbitration Course at IICS-CEU São Paulo. PhD and Master Degree from USP (University of São Paulo). Co-head of the arbitration team of LO Baptista-SVMFA (Brazil). VicePresident of the International Council for Commercial Arbitration since 2014. Chaired the Brazilian Arbitration Committee (CBAr) from 2009 to 2013. Participates as a committee member in various academic and arbitral institutions. Acts as counsel and arbitrator.

1 See Lucy Reed and Robert Kirkness "Old Seeland, New Netherland and New Zealand: Some Thoughts on the Possible 'Discovery' of Investment Treaty Arbitration in New Zealand" (2012) 43 VUWLR 687. This article is based on the inaugural New Zealand Law Foundation International Dispute Resolution Lecture, entitled "Zealand Old and New: International Arbitration and Trade", delivered by Lucy Reed at Victoria University of Wellington on 7 November 2012.

2 See Catherine Rogers "A Window into the Soul of International Arbitration: Arbitrator Selection, Transparency and Stakeholder Interests" (2015) 46 VUWLR 1179. 
important subject. I am part of the subject since I am a Latin American woman from a developing country.

Why did I choose this subject for my speech? I believe that it is an essential debate that we need to have nowadays and onwards if we want to guarantee the legitimacy of international arbitration. So far international arbitration has grown steadily, but there is a lot of work ahead of us as the world has changed significantly in the last 35 years as a result of globalisation. We are all connected; we exchange products, ideas, money and experiences globally at an incredibly fast pace. We are more plural. And if we want a well-accepted international dispute method, it needs to represent this plurality - all this diversity that we can easily perceive. Otherwise those new players - of whom we will talk about in a while - will search for other tools to solve their disputes.

When talking about diversity, we are not just talking about gender issues. We are talking about race and my main area of concern, nationality. We are talking about age, and also the participation of non-lawyers in this method that we have chosen to solve disputes - that is, arbitration.

The common arbitrator is male, white, mature, a lawyer and from a developed or western country. Is this a problem? So far, it has not been a problem at all - in fact, those well experienced arbitrators helped substantially the development of arbitration - but we will see that with the increase of cases and the new players, the scenario will have to change.

The first time that this issue of diversity was discussed openly was last year, in 2014, in Miami. The International Council for Commercial Arbitration's (ICCA) Miami Congress had two main streams in its programme: there was a discussion of practical issues - precision in international arbitration - and a philosophical discussion about the legitimacy of arbitration as a system. ${ }^{3}$ Why legitimacy? It has to do with diversity. ${ }^{4}$ Arbitration - especially investment arbitration - is receiving some criticism that needs to be addressed. Otherwise, what is going very well may come into a crisis in the near future.

Before I jump into some statistics, I want to briefly mention what Albert Jan van den Berg and his predecessor, Jan Paulsson, are doing in ICCA. ICCA is a well-known academic institution. Originally it was a group of 45 practitioners of international arbitration, mainly from Europe and North America. In the last few years, van den Berg and Paulsson realised that the world has changed and that ICCA had to open to different nationalities and different perspectives. Nowadays, ICCA is open to everybody and it has more than 1,000 members. You are probably following a little bit of ICCA's work since you, together with Australia, will host the ICCA 2018 Congress - the most important arbitration conference in the world, held every two years.

3 See "Miami Congress" International Council for Commercial Arbitration <www.arbitration-icca.org>.

4 The speakers on this subject were Christophe Seraglini, Darius J Khambata, Jacomijn J van Haersolte-van Hof and VV Veeder QC. See Albert Jan van den Berg (ed) Legitimacy: Myths, Relaities, Challenges ICCA Congress Series No. 18 (Kluwer Law International, Alphen aan den Rijn, 2014) at 579-660. 
The 45 who used to be the only ICCA members are now the governing board, and now ICCA has lots of different perspectives. For instance, there are various judges, and the dialogue with judges is very important for us counsel and arbitrators in international arbitration; also, there are corporate lawyers, who help us see the client's perspective. There are various women and members from Latin American, Asia and Pacific, including David Williams from New Zealand and many from African Countries. It is an incredible group of people with very different experiences allowing us at ICCA to have a unique exchange of ideas.

In order to start to address the issue of diversity in international arbitration, let's have a look at some statistics: ${ }^{5}$

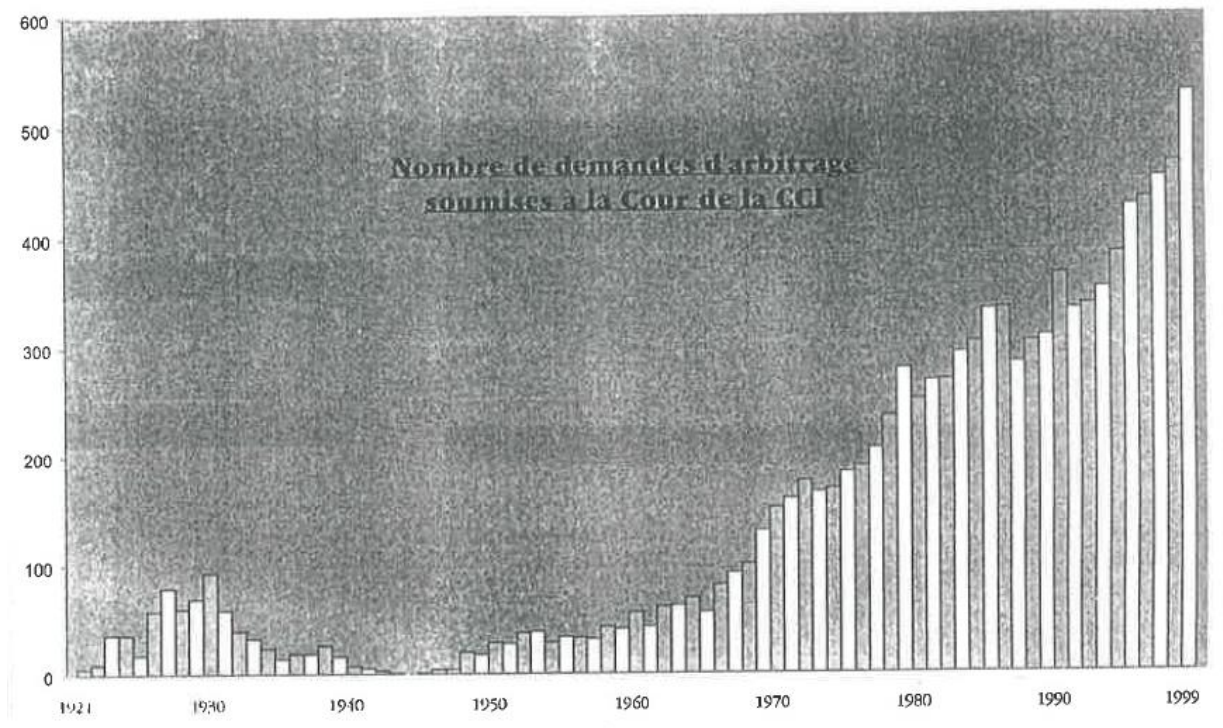

Statistics from the International Chamber of Commerce (ICC) from 1999 show that modern arbitration is something quite new, even though there are institutions like the London Court of International Arbitration (LCIA) and the ICC that are more than 100 years old. Also, it makes clear that arbitration develops as the economy develops. The number of cases in international arbitration began to rise from the end of the Second World War onwards. At the end of the last century, ICC was receiving roughly 500 cases per year and now it receives more than 800 .

The incredible growth of cases can also be identified in the International Centre for the Settlement of Disputes' (ICSID) statistics. The first case was in 1972 and there were only few cases

5 The figures in this text were part of the author's PowerPoint presentation. 
for a long period of time. The numbers started to rise from 1997 onwards, and currently there are a total number of 525 cases. $^{6}$

Chart 1: Total Number of ICSID Cases Registered, by Calendar Year:

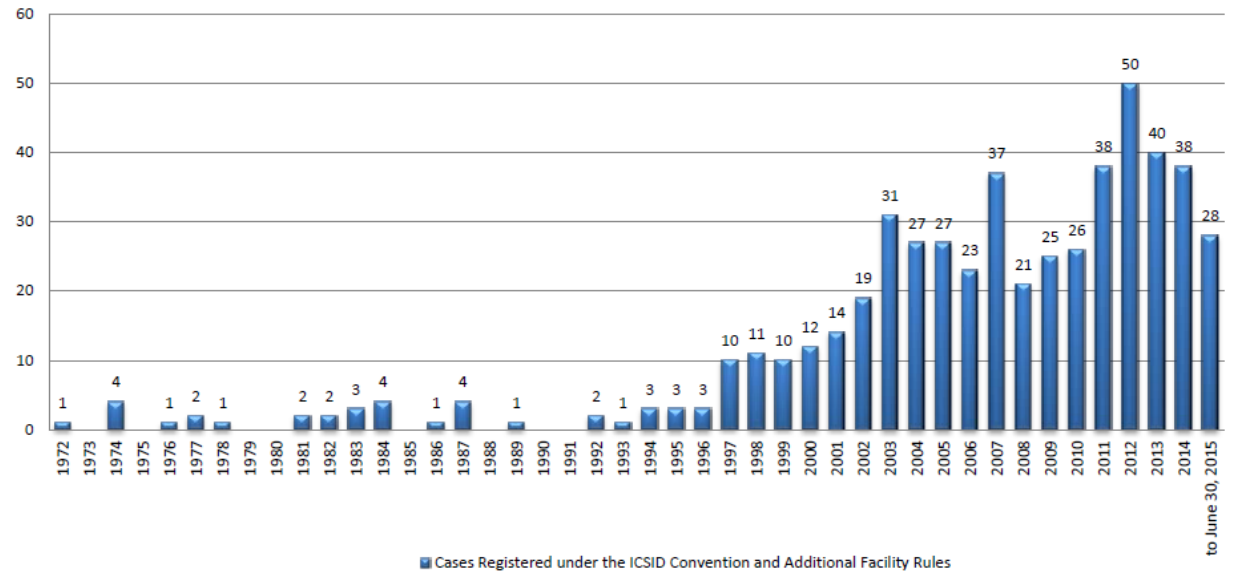

Not only there was a growth of cases in certain institutions (and if we look at the LCIA statistics, a growth will be seen as well) but also there was a substantial increase of new institutions in the last decades. Whereas 30 to 40 years ago there were three or four institutions, nowadays there are dozens. For instance, there is the International Centre for Dispute Resolution (ICDR) within the American Arbitration Association (AAA), three great Brazilian institutions (CAM-CCBC, FIESP and AMCHAM-SP), the Hong Kong International Arbitration Centre (HKIAC), and the Singapore International Arbitration Centre (SIAC), all of which are doing excellent work. And there are Institutions in Sweden, Italy, Peru, Belgium, Colombia, Spain, Chile and many other places.

In a nutshell, 30 years ago there were few institutions with few cases, and now there are dozens of institutions with hundreds of cases.

The pool of arbitrators, though, remained closed. The statistics show the centralisation of arbitrators in North America and Europe. Thirty years ago, parties from Western Europe were responsible for 62 per cent of cases, while in 2013, only 33 per cent of the parties were from Northern and Western Europe (please see the two slides below).

6 International Centre for Settlement of Investment Disputes The ICSID Caseload - Statistics (Issue 2, Washington DC, 2015) at 7. 


\begin{tabular}{|c|c|c|c|c|c|c|c|c|c|c|}
\hline \multicolumn{11}{|l|}{ Origine des parties } \\
\hline & 1982 & 1983 & 1984 & 1985 & 1986 & 1987 & 1988 & 1989 & 1990 & 1991 \\
\hline EUR. OCCIDENT. & $62 \%$ & $57,2 \%$ & $56,9 \%$ & $52,5 \%$ & $54,9 \%$ & $56,5 \%$ & $57,1 \%$ & $56,2 \%$ & $59,8 \%$ & $63,8 \%$ \\
\hline EUR. C. \& ORIENT. & $5,8 \%$ & $3,8 \%$ & $4,1 \%$ & $2,6 \%$ & $3,5 \%$ & $3,7 \%$ & $4,2 \%$ & $2,2 \%$ & $2,3 \%$ & $5,3 \%$ \\
\hline MOYEN ORIENT & $5,8 \%$ & $8 \%$ & $7,4 \%$ & $5,9 \%$ & $7,4 \%$ & $4 \%$ & $5,1 \%$ & $5,1 \%$ & $4,3 \%$ & $4,2 \%$ \\
\hline AFRIQUE DU NORD & $3,9 \%$ & $5,1 \%$ & $6,6 \%$ & $5,6 \%$ & $6,2 \%$ & $6,2 \%$ & $4,3 \%$ & $4,4 \%$ & $3 \%$ & $2 \%$ \\
\hline AFRIQUE & $2,5 \%$ & $3,1 \%$ & $3 \%$ & $4,2 \%$ & $3,2 \%$ & $4 \%$ & $5,5 \%$ & $5,5 \%$ & $2.2 \%$ & $2,1 \%$ \\
\hline $\begin{array}{l}\text { AMERIQUE DU NORD } \\
\text { (USA \& CANADA) }\end{array}$ & $9,1 \%$ & $12,5 \%$ & $10,5 \%$ & $15,3 \%$ & $15 \%$ & $13,5 \%$ & $13,1 \%$ & $12,9 \%$ & $14,9 \%$ & $12 \%$ \\
\hline $\begin{array}{l}\text { AMERIQUE LAT. } \\
\text { \& CARAIBES }\end{array}$ & $5,8 \%$ & $3,4 \%$ & $4,9 \%$ & $4,2 \%$ & $3,5 \%$ & $3,8 \%$ & $4,1 \%$ & $4,4 \%$ & $2,3 \%$ & $3,3 \%$ \\
\hline $\begin{array}{l}\text { ASIE DU SUD } \\
\& \text { DU SUD-EST }\end{array}$ & $3,3 \%$ & $3,1 \%$ & $3,9 \%$ & $5,6 \%$ & $3 \%$ & $4,9 \%$ & $3,1 \%$ & $8,7 \%$ & $10,5 \%$ & $6,6 \%$ \\
\hline PACIFIQUE & $1,9 \%$ & $3,8 \%$ & $2,7 \%$ & $4,1 \%$ & $3,3 \%$ & $3,5 \%$ & $3,5 \%$ & $0,6 \%$ & $0,7 \%$ & $0,7 \%$ \\
\hline
\end{tabular}
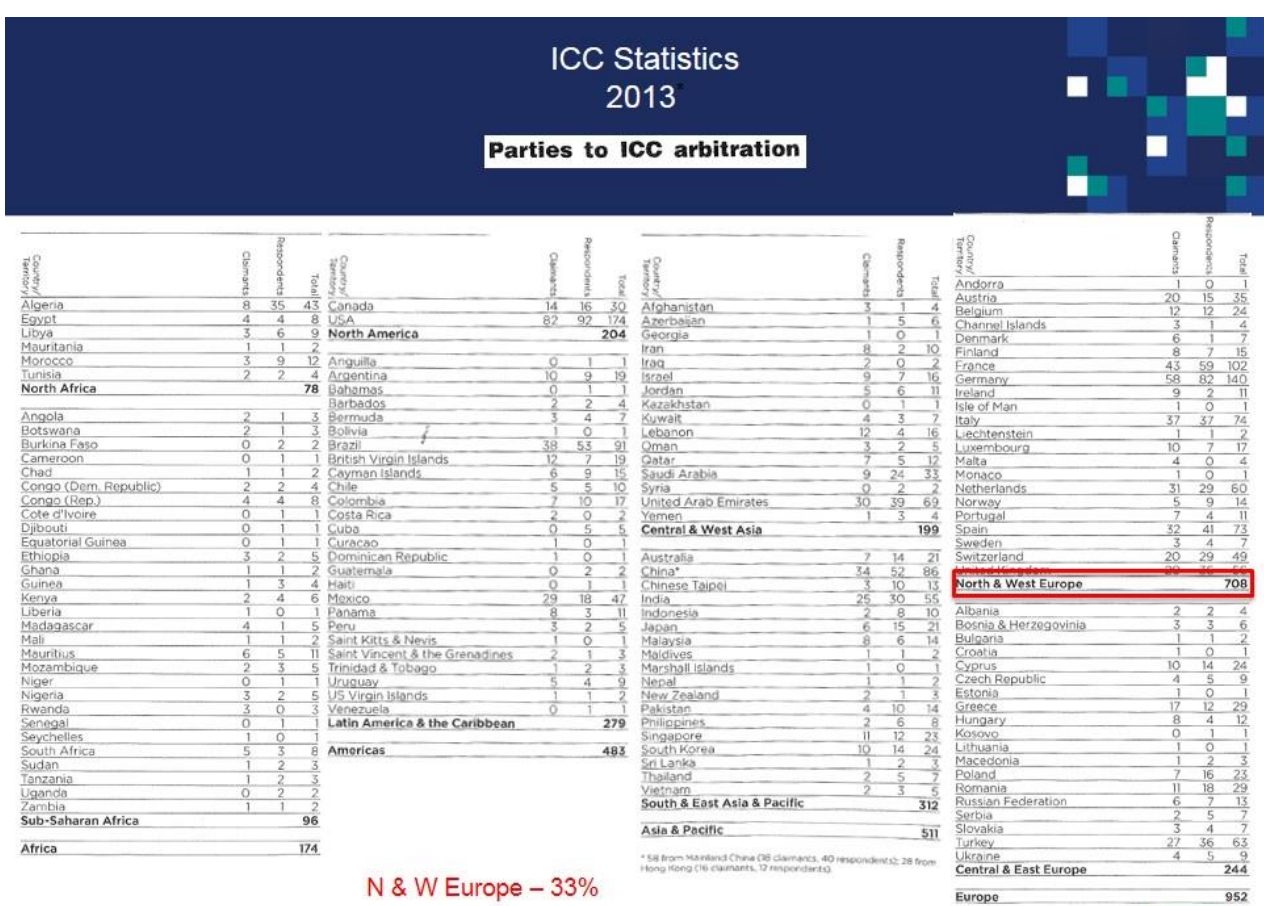

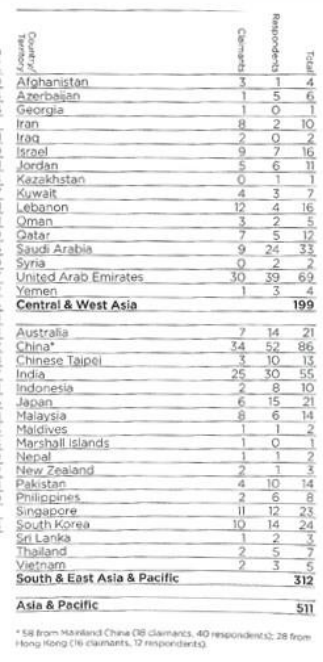

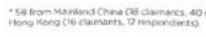

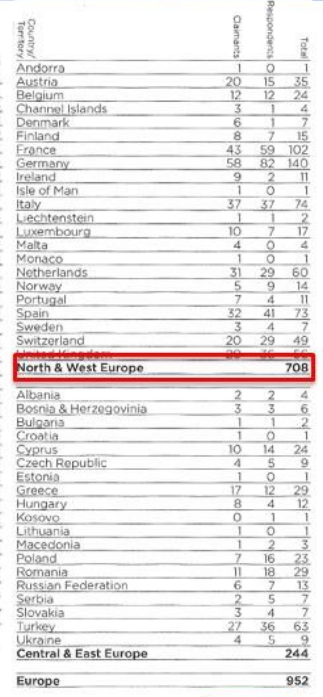


From the information given by the ICC in 2013, there is also a breakdown by country. One can see the increase number of cases in Africa, Latin America and Asia-Pacific.

The following chart - parties per region from 1990-2013 - shows 23 years of data, in which the parties' participation per region has changed significantly, while the concentration of American and European arbitrations remains roughly the same (from 2009-2013). This data confirms that although the number of cases has grown significantly due to new players, the pool of arbitrators remains quite flat.

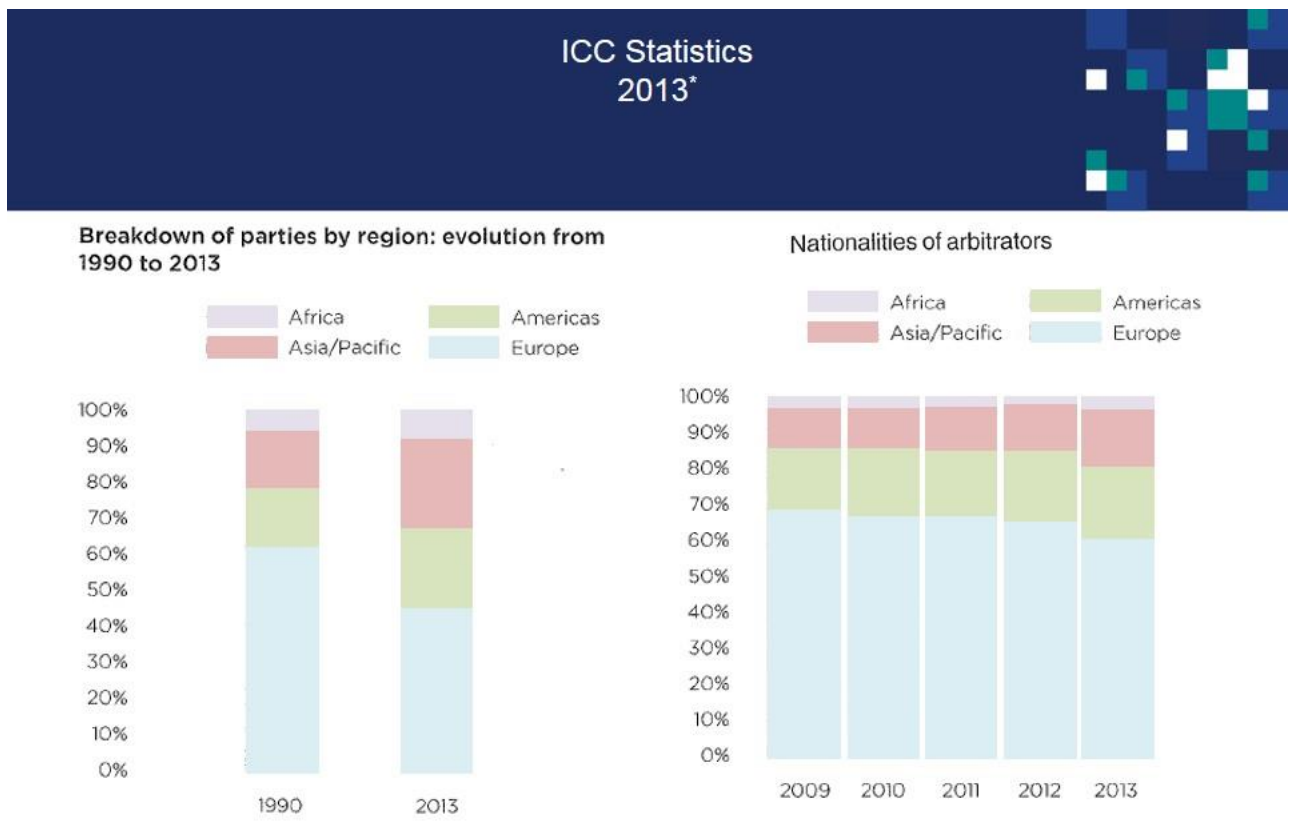

Considering the percentage of arbitrators that are sitting in ICC cases, the vast majority - almost 46 per cent - are from the United Kingdom, Switzerland, France, the United States and Germany.

Brazil is playing an important role in number of parties lately, though still not as important considering the participation of Brazilian arbitrators (in 2014, Brazil, became the third jurisdiction in relation to parties to ICC cases, just after the United States and France). 

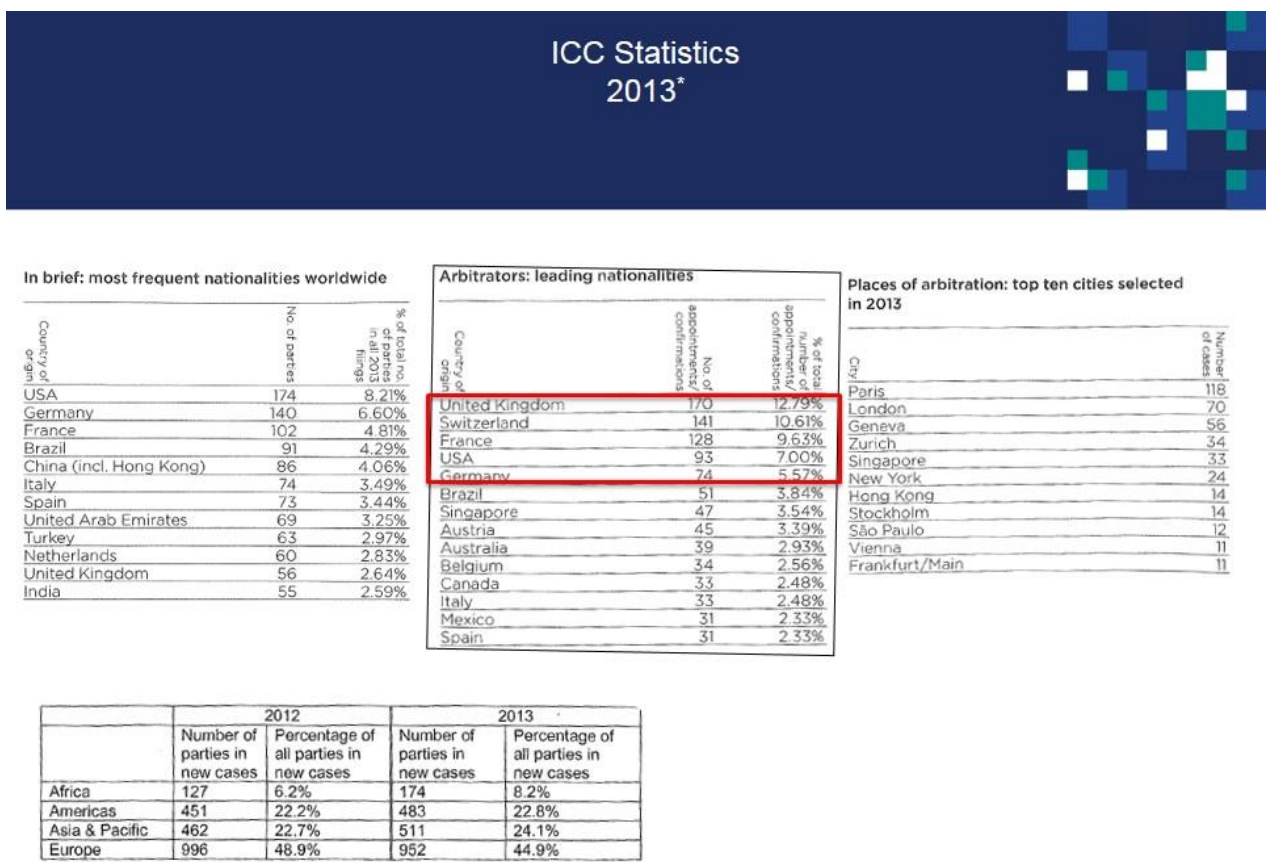

COUR INTERNATIONALE D’ARBITRAGE DE LA CCI. Bulletin. Paris, n. 1, v. 25 , Jul. 2014, pp. 9,12

In the ICCA conference of 2014, research was undertaken with all the attendees for the first time in a conference like this. ${ }^{7}$ It was a unique opportunity to discuss with the arbitration practitioners what is going on and what needs to be done in the future. From the 1,000 attendees, approximately 500 answered the questionnaire. Their answers reinforced what the ICC statistics show: 82.4 per cent of the arbitrators are men, arbitrators are predominantly Europeans or from other developed countries, and women in international arbitration are younger than men.

7 Lucy Reed, chair of the ICCA Program Committee at that time, had this excellent idea. The research was conducted by Susan D Franck, James Freda, Kellen Lavin, Tobias Lehmann and Anne van Aaken. See van den Berg, above n 4, at 33-122. 
ICCA Respondents

Arbitrators and counsel

Descriptive Statistics of Gender and Age for All ICCA Respondents, the Subset of those Working as Arbitrators and the Subset of those Working as Counsel

\begin{tabular}{|l|l|l|l|}
\hline Variables & All & Arbitrators & Counsel \\
\hline $\begin{array}{l}\text { Respondent Gender: } \\
\text { Percentage and Frequency }\end{array}$ & & & \\
\hline Women & $\mathbf{2 5 . 5} \%(\boldsymbol{n}=\mathbf{1 3 4})$ & $17.6 \%(n=46)$ & $24.0 \%(n=99)$ \\
\hline Men & $\mathbf{7 4 . 5} \%(\boldsymbol{n}=\mathbf{3 9 2})$ & $82.4 \%(n=216)$ & $76.0 \%(n=314)$ \\
\hline Total Respondents & $100 \%(n=526)$ & $100 \%(n=262)$ & $100 \%(n=413)$ \\
\hline Respondent Age: & & & \\
\hline Mean & 48.5 & 54.4 & 48.0 \\
\hline Median & 47.0 & 53.0 & 46.0 \\
\hline Total Respondents & 514 & 253 & 406 \\
\hline Age as a Function of Gender: & & & \\
\hline Age of Women & & & \\
\hline Mean & $\mathbf{4 2 . 0}$ & 47.5 & 41.3 \\
\hline Median & 40.0 & 45.0 & 40.0 \\
\hline Total Number of Women & 128 & 46 & 96 \\
\hline Age of Men & & & \\
\hline Mean & $\mathbf{5 0 . 6}$ & 55.8 & 50.0 \\
\hline Median & 50.0 & 55.0 & 50.0 \\
\hline Total Number of Men & 386 & 216 & 310 \\
\hline
\end{tabular}

$\rightarrow$ Arbitrators and counsel are predominantly men

$\rightarrow$ Women working with arbitration are younger than men

-FRANCOIS-PONCET, Sarah apud GOLDHABER, Michael D. Madame Law Présidente: A woman who sits as president of a major arbitral tribunal is a rare creature. Why? American Lawyer, Focus Europe, Summer 2004. Available at hittps://fr.groups.yahoo.com/neo/groups/arbitrage-

adr/conversations/messages/447 [visted on September 28th, 2015] Legitimacy: myths, realities challenges. ICCA Congress Series, v. 18, pp. 33-122, 2015, p. 47 


\section{ICCA Respondents \\ Arbitrators and counsel}

Percentages and Frequency Distributions (in parentheses) of Legal Education, Native Language, Continent and Nationality for All ICCA Respondents, the Subset of those Working as Arbitrators and the Subset of those Working as Counselt:"

\begin{tabular}{|l|l|l|l|}
\hline Variables & All & Arbitrators & Counsel \\
\hline Continent & & & \\
\hline Europe & $36.4 \%(n=183)$ & $48.2 \%(n=121)$ & $37.2 \%(n=148)$ \\
\hline North America & $33.6 \%(n=169)$ & $27.9 \%(n=70)$ & $31.4 \%(n=125)$ \\
\hline South America & $12.7 \%(n=64)$ & $9.6 \%(n=24)$ & $14.3 \%(n=57)$ \\
\hline Asia & $10.9 \%(n=55)$ & $10.0 \%(n=25)$ & $11.1 \%(n=44)$ \\
\hline Australia / New Zealand & $4.6 \%(n=23)$ & $4.0 \%(n=10)$ & $4.8 \%(n=19)$ \\
\hline Africa & $1.8 \%(n=9)$ & $0.4 \%(n=1)$ & $1.3 \%(n=5)$ \\
\hline Total Respondents & 503 & 251 & 398 \\
\hline Nationality & & & \\
\hline United States & $29.0 \%(n=145)$ & $23.2 \%(n=58)$ & $26.8 \%(n=106)$ \\
\hline United Kingdom & $10.6 \%(n=53)$ & $9.6 \%(n=24)$ & $10.4 \%(n=41)$ \\
\hline Brazil & $8.6 \%(n=43)$ & $7.2 \%(n=18)$ & $9.6 \%(n=38)$ \\
\hline France & $5.0 \%(n=25)$ & $8.8 \%(n=22)$ & $6.1 \%(n=24)$ \\
\hline Australia & $3.8 \%(n=9)$ & $2.8 \%(n=7)$ & $4.3 \%(n=17)$ \\
\hline Germany & $3.6 \%(n=18)$ & $4.8 \%(n=12)$ & $3.0 \%(n=12)$ \\
\hline Canada & $3.4 \%(n=17)$ & $4.8 \%(n=12)$ & $4.1 \%(n=16)$ \\
\hline Switzerland & $2.8 \%(n=14)$ & $5.6 \%(n=14)$ & $3.5 \%(n=14)$ \\
\hline China & $2.6 \%(n=13)$ & $1.2 \%(n=3)$ & $1.5 \%(n=6)$ \\
\hline India & $2.4 \%(n=12)$ & $1.6 \%(n=4)$ & $2.8 \%(n=11)$ \\
\hline Other Primary Nationalities & $28.1 \%(n=151)$ & $30.4 \%(n=76)$ & $28.4 \%(n=110)$ \\
\hline Total Number of Different Primary & 58 & 41 & 47 \\
\hline Nationalities & & 250 & 395 \\
\hline Total Respondents & 500 & 2.05 & \\
\hline
\end{tabular}

Total Respondents
FRANCK, Susan D.; FREDA, James et al. International Arbitration: Demographics, Precision and Justice. In VAN DEN BERG, Albert Jan (ed.).
Legitimacy: myths, realities challenges. ICCA Congress Series, v. 18, pp. 33-122, 2015, p. 50, table 4. Table adapted.

$\rightarrow$ Arbitrators are predominantly Europeans or from other developed countries

I want to draw your attention to two other interesting results: first, every attendee who said he or she was an arbitrator was asked if they had ever worked with an arbitrator from a developing country. Astoundingly, 40.2 per cent said never. Another 38.6 per cent said that he or she had sat with one arbitrator from a developing country only few times (1-5 times). One obvious conclusion is that, although we have a large percentage of cases involving developing countries, 40 per cent of those cases have never had the participation of a developing country arbitrator. It is also interesting to see that when asked if they have had the opportunity to sit with two developing country arbitrators, 59.4 per cent said no. And the ICCA conference was in Miami, where there are hundreds of Latin Americans. Even then, there was a lack of proper representation of regional players. 


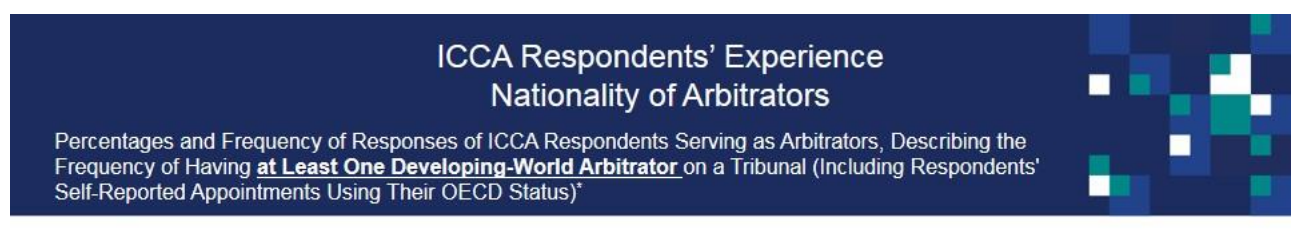

\begin{tabular}{|l|l|l|}
\hline Answer & $\begin{array}{l}\text { Response } \\
\text { Percentage }\end{array}$ & $\begin{array}{l}\text { Response } \\
\text { Frequency }\end{array}$ \\
\hline $\begin{array}{l}\text { Never had Tribunal with a Developing-World } \\
\text { Arbitrator }\end{array}$ & $40.2 \%$ & 102 \\
\hline 1-5 Tribunals with a Developing-World Arbitrator & $38.6 \%$ & 98 \\
\hline 6-10 Tribunals with a Developing-World Arbitrator & $9.8 \%$ & 25 \\
\hline 10+ Tribunals with a Developing-World Arbitrator & $11.4 \%$ & 29 \\
\hline Total & $100.0 \%$ & 254 \\
\hline
\end{tabular}

Percentages and Frequency of Responses of ICCA Respondents Serving as Counsel, Describing the Frequency of Having Two or More Developing-World Arbitrator on a Tribunal ${ }^{*}$

\begin{tabular}{|c|c|c|}
\hline Answer & $\begin{array}{l}\text { Response } \\
\text { Percentage }\end{array}$ & $\begin{array}{l}\text { Response } \\
\text { Frequency }\end{array}$ \\
\hline $\begin{array}{l}\text { Never had Tribunal with Multiple Developing-World } \\
\text { Arbitrators }\end{array}$ & $59.4 \%$ & 228 \\
\hline 1-5 Tribunals with Multiple Developing-World Arbitrators & $31.0 \%$ & 119 \\
\hline 6-10 Tribunals with Multiple Developing-World Arbitrators & $4.1 \%$ & 16 \\
\hline 10+ Tribunals with Multiple Developing-World Arbitrators & $5.5 \%$ & 21 \\
\hline Total & $100.0 \%$ & 384 \\
\hline
\end{tabular}

Finally, regarding the participation of women as arbitrators, 32.2 per cent of the attendees who are arbitrators said that they had never had a woman sitting on their arbitral panels. A large percentage -43.4 per cent - said that they had had a woman sitting in a panel only a few cases $(1-5$ cases). 


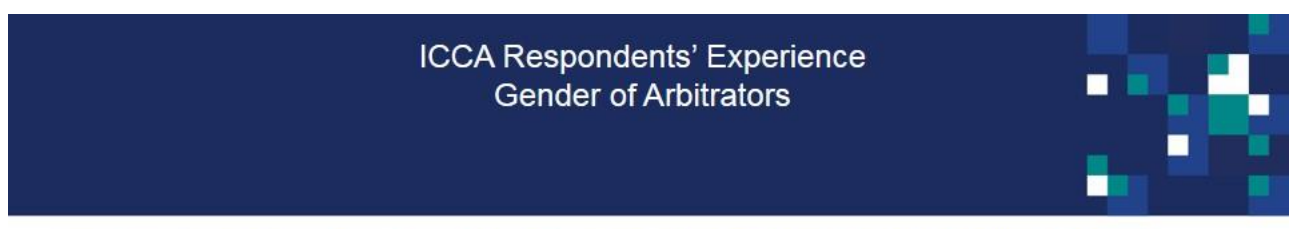

Percentages and Frequency of Responses of ICCA Respondents Serving as Arbitrators, Describing the Frequency of Having at Least One Woman on a Tribunal (Including Women's Self-Reported Appointments)

\begin{tabular}{|l|l|l|}
\hline Answer & $\begin{array}{l}\text { Response } \\
\text { Percentage }\end{array}$ & $\begin{array}{l}\text { Response } \\
\text { Frequency }\end{array}$ \\
\hline $\begin{array}{l}\text { Never had Tribunal with a } \\
\text { Woman }\end{array}$ & $32.2 \%$ & 83 \\
\hline $1-5$ Tribunals with a Woman & $43.4 \%$ & 112 \\
\hline $6-10$ Tribunals with a Woman & $8.9 \%$ & 23 \\
\hline $10+$ Tribunals with a Woman & $15.5 \%$ & 40 \\
\hline Total & $100.0 \%$ & 258 \\
\hline
\end{tabular}

-FRANCK, Susan D.; FREDA, James et al. International Arbitration: Demographics, Precision and Justice. In VAN DEN BERG, Albert Jan (ed.)

Legitimacy: myths, realities challenges. ICCA Congress Series, v. 18, pp. 33-122, 2015, p. 110, table 16.
Idem, p. 110 .

The other question that was posed to the attendees was whether the issue of diversity is something that we need to address in the coming years. Approximately 56 per cent of the attendees said yes (the majority either strongly agreed or somewhat agreed) in the sense that something needs to be done in relation to the subject. Breaking down the attendees between women and men, more than half of the women said they strongly agreed that there is something to be done, compared to only 20 per cent of the men. Nevertheless, more than 76 per cent of the women $(50.4$ per cent who strongly agreed plus 26.8 per cent who somewhat agreed) and a large percentage of the men (19.2 per cent who strongly agreed plus 32.5 per cent who somewhat agreed) agreed that there is something to be done. 


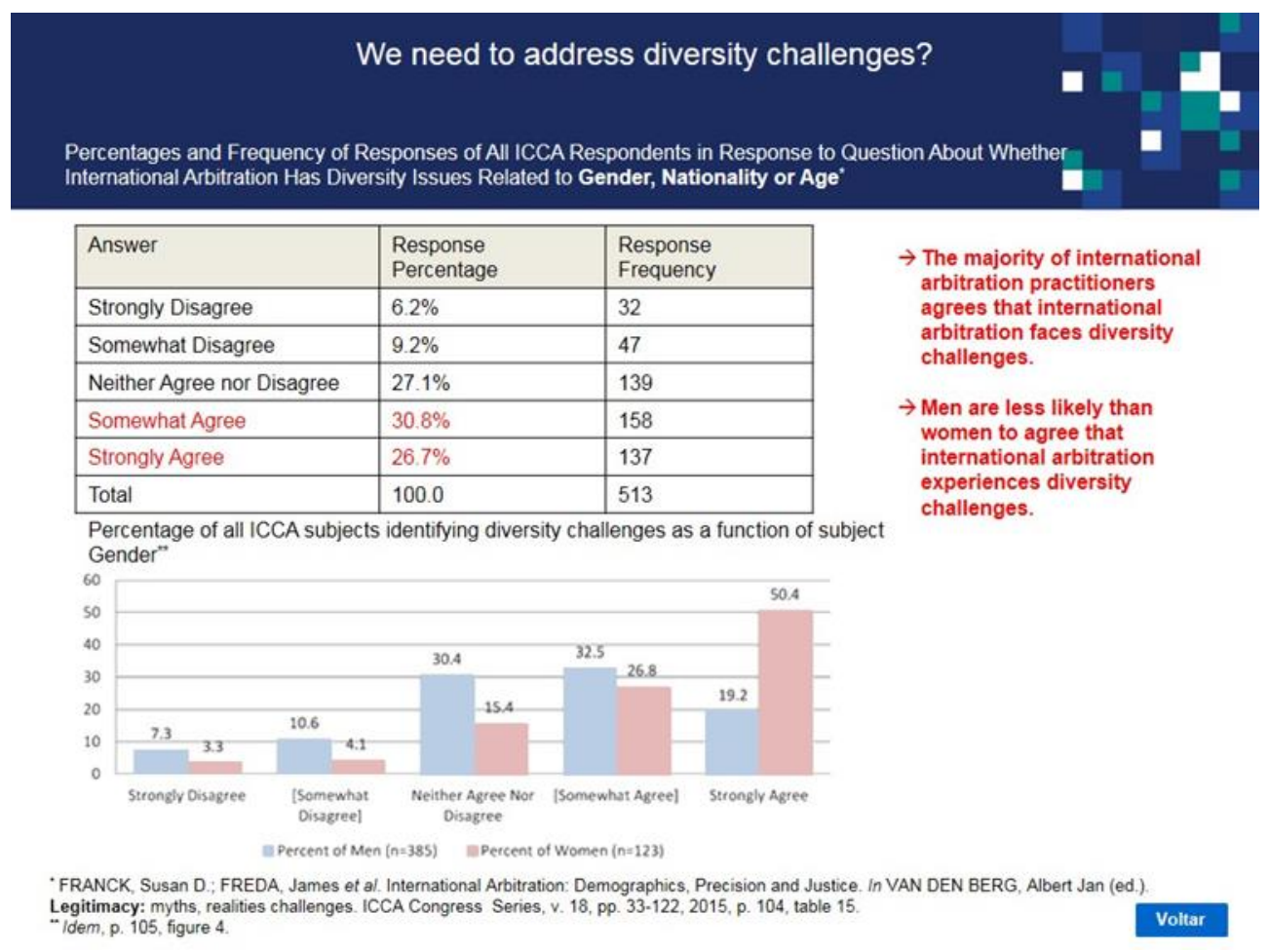

The findings of the 2014 ICCA research are: "overall, the 'median' ICCA attendee was a male, 50 years old, with some common law legal training and from a developed state"; "[o]verall these results suggest that: (1) women's presence in international arbitration was relatively small; and (2) the proportion of developing-world arbitrators was relatively small"; "[t]he data reflected arguably disproportionate levels of representation by men from states in North America and Europe, which have high levels of economic development"; and "[u]ltimately the data supported, rather than disproved claims that international arbitration is a 'white male game'". 8

It is understandable that parties and counsel keep on choosing the same names as arbitrators, not only because they are experienced and good, but also as a sort of "insurance policy". If something happens to the case, if the company loses, the one that has chosen the arbitrator is not to be blamed.

However, I would say that the "insurance policy" aimed for by the parties may not be working as expected, or at least not in every case. This is mainly due to the lack of availability of some

8 See van den Berg, above n 4, at 97 and 116. 
arbitrators, considering the growth of cases, and to some low-quality decisions issued by arbitrators that do not have enough time to dedicate to a certain case. It is also worth mentioning the increasing number of cases with conflicted arbitrators, making it very hard to constitute a panel.

If there are at least some poor quality decisions, there is room for improvement. Otherwise, a company that has chosen arbitration at a certain moment and has no option to appeal from a poor decision might never go to international or national arbitration again.

But it is not only the issue of opening up the pool of arbitrations that is relevant. We have to benefit from the fantastic plurality that we have nowadays. One of the speakers from our panel at 2014 ICCA Conference, Darius J Khambata, from India, quoted Benjamin Franklin in a sentence that illustrates the issue of diversity very well: "If everyone is thinking alike, then no one is thinking."

Not only do gender and nationality need to be addressed, but expertise also. The parties want different ideas and different backgrounds from the arbitral panels. As an example, in a construction case, it is possible that an engineer would enhance the quality of the evidence assessment and therefore, will help to issue a better decision. Or, in an intellectual property case, a specialist in intellectual property sometimes makes a total difference.

Johnny Veeder mentioned that it would be a waste of human resource if we do not pay attention to diversity. ${ }^{9}$ Interestingly, recently the Vice President of the International Court of Justice, Judge Abdulqawi Ahmed Yusuf, from Somalia, gave a speech about the same subject. ${ }^{10}$ There is a huge pressure for African countries to participate in international arbitration and Mr Yusuf said that if the arbitration community do not welcome Africans, Africans will reject it. This is one of the risks arbitration faces in the future.

There are two main actions to take: to expand the pool of arbitrators that are able to sit on all those arbitration cases that keep on growing, and to do it respecting the diversity within the players in order to preserve the legitimacy of the system.

It is also important to say that, although there is a consensus that diversity should be stimulated, it should not be at any cost. Experience and quality are crucial in international arbitration (especially because there is no appeal). The young and brilliant professionals in each jurisdiction should be encouraged to participate in the arbitration community as they will be the future arbitrators.

9 See in van den Berg, above n 4, at 660: "The objective is indisputable: inadvertent discrimination based on gender and race damages arbitration, because it assumes unthinkingly, that a class of persons have always the relevant qualities and that another class always do not, thereby wasting the human resources available to arbitration."

10 See "London: Honouring Judge Abdulqawi Ahmed Yusuf" (16 October 2015) Global Arbitration Review <www.globalarbitrationreview.com>. 
Party autonomy should also be preserved, of course, but as responsible practitioners, it is up to us and the arbitral institutions to prepare the future.

Thank you very much. 